\title{
Analysis of the Misuse of Legal English Terminology in Legal Scientific Work Abstracts
}

\author{
Procedural Law Department \\ Faculty of Law Udayana University Bali \\ Denpasar, Indonesia \\ satyayudha.dananjaya@fl.unud.ac.id \\ English Literature and Linguistics Department \\ Faculty of ArtsUdayana University Bali \\ Denpasar, Indonesia \\ senja.dananjaya@yahoo.com \\ International Law Department \\ Faculty of Law Udayana University Bali \\ Denpasar, Indonesia \\ arassamsitha@yahoo.com
}

Nyoman Satyayudha Dananjaya ${ }^{1}$, Putu Ayu Asty Senja Pratiwi ${ }^{2}$, Putu Aras Samsithawrati $^{3}$

\begin{abstract}
Scientific work in law field has its own characteristics, including the legal English terminology. Legal English is actually slightly different with general English. Nowadays, there are lots of inappropriate process of language transfer from Bahasa to English can be found especially in abstract, as part of the scientific work related to law field. Thus, such issue will affect the abstract validity as a representation of the contents of the scientific work as a whole. This study used an empirical juridical approach which employed non-probability sampling technique and qualitative descriptive analyses. The results show that the misuse of legal English terminology towards abstract of legal, scientific works may occur due to word-for-word translation, free translation, and literal translation. Based on empirical research, such misuse occurred due to the use of online translation engine which mostly caused by the ignorance of abstract's authors on the structure of standard academic writing (SP-O)in the source language and asking help from colleagues who mostly do not have legal background and has minimum knowledge of legal English terminology.
\end{abstract}

Keywords: misuse, terminology, legal English, abstract

\section{INTRODUCTION}

Scientific work is a written and published report that describes the results of research or assessment that has been done by a person or a team by fulfilling the rules and scientific ethics that are confirmed and obeyed by the scientific community. Accuracy is very important in this sense because the data, conclusions, and information contained in the scientific work are used as a reference for other researchers in conducting preliminary or advanced research. Scientific work is actually a container to develop knowledge or science. Each scientific work has its characteristics. For example the use of theories as for the basis of thinking or framework to discuss issues raised and later to be solved which is logical and systematic. There is one item that is very important in scientific work, namely abstract. The abstract is an element in a scientific work that must exist and can be understood.It might be said that good scientific work must contain abstract. Abstract is a summary of the entire contents of scientific work. It constitutes a representation of the content of such scientific work.

Scientific work in law field has its characteristics, including the legal English terminology. Legal English is actually slightly different with general English. Nowadays, there are lots of inappropriate process of language transfer from Bahasa to English can be found especially in abstract, as part of the scientific work related to law field. Thus, such issue will affect the abstract validity as a representation of the contents of the scientific work as a whole. This is of course very important to be examined because the legal terminology when it is translated into English and is not used carefully and appropriately, it may have a different meaning which will potentially destroy the essence of scientific work. Thus, in examined such issues, this study used an empirical juridical approach which employed non- 
probability sampling technique and qualitative descriptive analyses. For the empirical approach, we used depth interview to authors and reviewers of abstract of legal scientific works (journal, mini-thesis, thesis, dissertation) in Faculty of Law Udayana University, Bali.

\section{ANALYSIS AND DISCUSSION}

Nida and Taber (1967) (E.A Nida and Charles R.Taber,1974, p.12) in Hanafi (1986: 25) says that "Translating consist in producing in the receptor language the closest natural equivalent to the message of the source language, first in meaning and secondly in style." This means that with regard to translation, we should search for the nearest equivalent word to the recipient language of the source language, in terms of both the meaning and the style of the language. Thus translating means to divert the message contained in the source language into the target language in such a way that the person is reading or hearing the message in the target language has the same picture as the person reading or hearing the message in the source language. Larson (Mildred L.Larson,1984, p.17) states that when translating text, the purpose of translation is to achieve such idiomatic translation in an attempt to communicate the meaning of the source language text into the natural form of the target language. According to Catford (J.C. Catford, 1965, p.20), translation means transferring the source language to the target language. Translation is the replacement of textual material in the source language into the target language.

The following is the analysis towards the mistranslation by usingthe wrong methods which impact the translation results where such mistranslation or misuse of legal English terminology will be reviewed in morphology, syntax and semantic levels.

\section{A. Mistranslation Due to Word for Word Translation}

Word for word translation is a type of translation which still closely related to the word level. This translation can also be said as a type of translation that simply moves word for word in the source language to the target language without changing the wording of the source language into the target language. This translation is also not focused on differences in cultural point of view or sentence structure changes. The results of such translation method seem rigid and hard to understand. Examples of such mistranslation can be seen from the following table.

TABLE 1

MISTRANSLATION DUE TO WORD FOR WORD TRANSLATION

\begin{tabular}{lcc}
\multicolumn{1}{c}{ Bahasa } & $\begin{array}{c}\text { Word for Word } \\
\text { Translation }\end{array}$ & English \\
\hline $\begin{array}{l}\text { Undang- } \\
\text { Undang } \\
\text { Tamor } 40\end{array}$ & Law Number 40 Year 2008 & $\begin{array}{c}\text { Act No. } 40 \text { of } \\
2008\end{array}$ \\
Anak luar & child beyond mating & $\begin{array}{c}\text { child born out } \\
\text { of wedlock / } \\
\text { bawin }\end{array}$ \\
\end{tabular}

From table 1 it is noted that the translator uses a wordfor-word translation, in which the word "Undang-Undang" is translated in English into "Law" instead of "Act". Moreover, the word "Tahun" translated into "Year", where the word that should be used is "of" to give meaning to what year the law is stipulated. If the translator is using the word "Year", the legal term cannot be properly channeled, considering there is a misuse in the choice of word in the sentence. The use of word "Year" is actually showing that the translator has poor knowledge in legal English and lack of English understanding on the use of word structures.In the morphological level or the study of the smallest part of a sentence, the word, the word "Tahun" if literally translated from the source language is true that it should be "Year". However, in semantic learning, it is still quite wrong. Similarly, the word "Undang-Undang" in the source language is translated into "Law". In this case, the translator is obliged to pay attention to the terms in the target language to distribute equivalent meanings in the source language.

The second example shows the misuse found in the noun phrase "anak luar kawin" which is translated into "child beyond mating". In English, suchnoun phrasehas a term which is "bastard". Instead of it,the translator uses a wordfor-word translation. The word "anak" is translated to "child", the word "luar" translated into "beyond" and the word "kawin" is translated into "mating". The translator, in this case, uses the literal translation on every word-byword. This gives a different meaning to the term because of the incorrect choice of words that lead to the wrong wording rules and the absence of an element of cultural viewpoint. Of course, such misuses of legal terminologies reflect the abstract writers' lack of knowledge in understanding culture and structure of target language, which is English.

In relation to the above mistranslation, the result of empirical research on the informants show that the level of difficulty experienced by informants who are reviewers of journals / mini thesis / thesis / dissertation in scientific works in the field of law, as much as $34 \%$ of informant feel very difficult in understanding the legal asbtract in English because the authors translate it by word for word translation; as much as $33 \%$ informant feel difficult to understand because it appears that the authors translate the abstract in Bahasa into English by using online translation engine, which mostly caused by the ignorance of abstract's authors on the structure of standard academic writing (S-P$\mathrm{O})$ in the source language; and the remaining $33 \%$ informant feel quite easy because it has been translated according to the content. The results of this empirical study can be seen in diagram 1 below: 
DIAGRAM 1

THE DIFFICULTY LEVEL IN UNDERSTANDING LEGAL ABSTRACT IN ENGLISH

\section{The Difficulty Level in Understanding Legal Abstract in English}

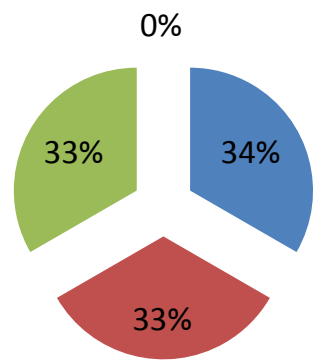

\author{
Very difficult to \\ understand the \\ abstract in \\ English since the \\ authors seem to \\ use word for \\ word translation
}

The diagram processed from the result of empirical research towards informants who serve as reviewer journal / mini-thesis / thesis/dissertation in the field of law.

\section{B. Mistranslation Due to Free Translation}

Free translation is a translation that is not tied to the search for equivalent words or sentences, but such search for the equivalent is more emphasized on a broader level than the sentence. This way of translation is more concerned with one party, where the translator reveals the contents of the translation freely regardless of the target language. Having complete freedom in translating a source language into the target language produces meaning that deviates from the message in the original text. This can happen to translators who have not mastered the source language. Examples of such mistranslation can be seen from the following table.

TABLE 2

MISTRANSLATION DUE TO FREE TRANSLATION

\begin{tabular}{lll}
\hline \multicolumn{1}{c}{ Bahasa } & Free Translation & \multicolumn{1}{c}{ English } \\
\hline $\begin{array}{l}\text { Otonomi asli } \\
\text { desa }\end{array}$ & $\begin{array}{l}\text { the village's native } \\
\text { autonomy }\end{array}$ & $\begin{array}{l}\text { Autonomy of } \\
\text { the village }\end{array}$ \\
$\begin{array}{l}\text { Pembuatan dan } \\
\text { perancangan } \\
\begin{array}{l}\text { Undang-Undang } \\
\text { Nomor 1 Tahun } \\
\text { 1974 }\end{array}\end{array}$ & $\begin{array}{l}\text { The manufacture } \\
\text { of the inside and } \\
\text { design the form of }\end{array}$ & $\begin{array}{l}\text { The enactment } \\
\text { and drafting of } \\
\text { Act Number 1 } 1 \\
\text { of 1974 } 1974\end{array}$ \\
\hline
\end{tabular}

From table 2, it is noted that the term "otonomiaslidesa is translated into "the village's native autonomy" by the translator. The translator in this case inadvertently gives the meaning that the original autonomy belongs to the village. This happens because the translator uses a possessive pronoun in the target language. The use of "s" means ownership in the target language. Using free translation method is actually beneficial for translators. Usually, the translator will be more comfortable with their own language understanding without being focused on the recipient or the reader of the target language. This method is very unfavorable to the reader in the target language.

Another example of mistranslation due to free translation can be seen in phrase "Pembuatan dan perancangan Undang-Undang Nomor 1 Tahun 1974" which is translated into "the manufacture of the inside and design of the form of Law no. 1 of 1974". In this case, the translator translates the word "pembuatan" into "manufacture of the inside", where the translator freely translates the meaning of "pembuatan" into the target language. However, such selection of words has errors in language rules in the target language due to the translator is lack of cultural understanding of the target language, which is English. In this context, the translator should use the word "enactment" which has relevant meaning with "pembuatan" in the target language.The mentioned mistranslation, of course, will harm the target language reader in understanding the meaning contained in the source language, which is Bahasa.

\section{Mistranslation Due to Literal Translation}

A literal translation is a word-for-word translation, but it hasdeformation which is adjusted to the language structure of the target language. It would be nice to use literal translation on a single sentence or short sentence. However, for complex sentences, many researchers argue that this translation is incorrect. This is because complex sentences have multiple clauses and phrases that have different subjects and predicates, so sometimes there is difficulty in translating main clause and subordinate clause into equivalent meanings and having a regular form of structure in the target language.

In translating a term, using literal translation regardless of cultural point of view is also wrong. The table below is an example of mistranslation due to literal translation.

TABLE 3

MISTRANSLATION DUE TO LITERAL TRANSLATION

\begin{tabular}{ccc}
\hline Bahasa & $\begin{array}{c}\text { Literal } \\
\text { Translation }\end{array}$ & English \\
\hline $\begin{array}{c}\text { Hukum adat } \\
\text { Putusan } \\
\text { pengadilan }\end{array}$ & Indigenous Law & Customary Law \\
Court decision & Court judgment \\
\hline
\end{tabular}

The first example of Table 3, the term "hokum adat" is literally translated as "indigenous law". In this case, "adat" literally means "indigenous" to the target language. However, in legal English, the term "hukum adat" should be translated as "customary law" which has the equivalent meaning to "hokum adat". The word "indigenous" is not wrong, but in this case, the meaning of the source language is not transmitted to the target language. This precisely reflects a lack of cultural understanding of the target language.

As for the second example, a similar case occurs, in which the term "putusan pengadilan" translated into "court decision". The word "decision" in the target language does have the meaning of "putusan" in the source language, but 
if literally translated, "decision" in the target language is actually "choice" in the source language. Meanwhile, in the source language view, we want the word "putusan" to be understood as the statement of a judge as outlined in writing and spoken by the judge in an open court to the public as part of the submitted lawsuit. Thus, the proper legal English term should be "judgment". In this case, the legal term that exists in the source language is not channeled into the target language.

\section{Translation Shifting}

In the translating process, or transferring the source language into the target language, it is very helpful for a translator to pay attention to the various adjustments in the translation. This adjustment itself is also noticed not only from a language point of view but also from a cultural point of view or term that has equivalent meaning to both languages. Adjustment, according to Nida and Taber (1969: 105), is divided into two groups, which are a structural adjustment and semantic adjustment which both resulting in translation shifting. The structure adjustment will result in a language form shifting, while semantic adjustment will lead to a meaning shifting. Catford (1965: 73) states that shift is a formal transfer of meaning from the source language to the target language. Catford also divides the shift into two types, namely the level shift and category shift.

In the legal language or legal terminology, language shifting is absolute, but if it focuses only on the form of language without regard to the meaning of the target language, it will also have an effect on the shift of meaning in the target language.

\section{E. Language Form Shifting}

In the language form shifting, Catford's theory (1965) states that the shift is divided into two, namely the level shift and category shift. According to Catford, a level shift occurs in the source language that is at a certain linguistic level having a translation language with an equivalent language system in different linguistic levels. This shifting, in general, occurs in vocabulary or lexical and grammatical, or often called grammatically. In legal language, the linguistic shifting in the translation of terminology in legal language can also occur. The second language form shifting is called the category shift. According to Catford (1965), category shift is the freedom to translate, where this shift follows many rules of the writing of the target language so that the translation does not look like a translation. The translation that using this shift method will focus on the form of sentence structure, each word, phrase and others that make up the sentence.

The absence of language form shifting can also lead to non-maximum or wrong translation. The below table is the example.

TABLE 4

ERROR IN LANGUAGE FORM SHIFTING

\begin{tabular}{lll}
\hline Bahasa & Mistranslation & English \\
\hline $\begin{array}{l}\text { Daftar calon } \\
\text { sementara dalam }\end{array}$ & The candidate list a & A list of \\
proses & while in the & candidates in the \\
& nomination process & nomination \\
\hline
\end{tabular}

\begin{tabular}{lll}
\hline $\begin{array}{l}\text { pencalonan } \\
\text { Asas pemberian } \\
\text { pinjaman yang } \\
\text { sehat }\end{array}$ & $\begin{array}{l}\text { Sound lending } \\
\text { principle }\end{array}$ & $\begin{array}{l}\text { Fair lending } \\
\text { principle }\end{array}$ \\
\hline
\end{tabular}

The first example in Table 4 above shows example of nominal phrase data in the source language, which is Bahasa, which translating "daftar calon sementara dalam proses pencalonan"into "the candidate list a while in the nomination process". The data does not use a good translation method, because there is an addition of lexicon which causing an error in the structure of the target language word, which is English. The phrase "daftar calon sementara" is translated to "the candidate list a while", where the noun phrase in the target language gets the addition of "a while lexicon" which caused the word structure error. The word "a while" literally means temporary or sementara in the source language, but, the selection of the lexicon in the target language is less precise. Supposedly, for the first example, the noun phrase data in table 4 is translated into "a list of candidates".

Moving on to the second example provided in Table 4, it is noted that there is still inappropriate structural shifting in noun phrase due to the wrong selection of word or lexicon in the target language. The phrase "asas pemberian pinjaman yang sehat" is then translated into "sound lending principle" in the target language. In the "pemberian pinjaman", the translation is correct by paying attention to the selection of word that has equivalent meaning. The word is translated into "lending" in the target language, which is English, in which there is a lexical reduction in the structure of the language.

\section{F. Meaning Shifting}

The meaning shifting often occurs in the process of translating from the source language to the target language. This is due to the difference in cultural point of view. Similarly, it also happens when translating terms in legal English. If the translator is focused solely on the literal translation without knowing the term in legal English with regard to the cultural point of view, thus, the translator cannot distribute the meaning of the legal term.

In translating legal term, the meaning is the most important thing to distribute correctly the content of the legal term. Each language has its own legal terminology. Hence, the translator who translates an article which contains legal terms must understand the legal term both in the source and target languages. Meaning shifting often occurs in translation. If the translation process engages with literal translation only, thus, it will eliminate the real meaning of the text and raise a big question to readers who understand the target language. For a better understanding, table 5 provides the example.

TABLE 5

MISTRANSLATION WHICH ELIMINATES THE MEANING

\begin{tabular}{lcl}
\multicolumn{1}{c}{ Bahasa } & Mistranslation & \multicolumn{1}{c}{ English } \\
\hline $\begin{array}{l}\text { Perusahaan } \\
\begin{array}{l}\text { Induk } \\
\text { Anak } \\
\text { perusahaan }\end{array}\end{array}$ & Parent Company & $\begin{array}{l}\text { Holding } \\
\text { Company }\end{array}$ \\
\hline
\end{tabular}


In the first example of table 5, the term "perusahaan induk" is translated to "parent company" in the target language, which should be translated into "holding company". This occurs because the translator does not pay attention to the culture of the target language, which is English. If the translator has lack of knowledge of the culture or terms in the target language, the translation which using only the literal method would be a major mistake. This can be seen from the first example where the word "induk" translated into "parent". Literally, "induk" in Bahasa has parallel meaning to the translation "parent" in the target language. However, in the context of the legal term, "perusahaan induk" which in Bahasa actually has meaning as the main company in charge of several companies incorporated into a group of companies cannot be well distributed into the target language, which is English.

A similar case occurs in the second example in table 9, where the term"anak perusahaan" translated into "child company" in the target language. The same thing happens because the translator lacks understanding of the cultural terms that exist in the target language. This error causes no distortion of meaning contained in the source language, which is Bahasa, to the target language, which is English. The legal term "anak perusahaan" should be translated into "subsidiary" in English.

For a broader picture, the table 6 below provides more examples of other mistranslations occur in the writing of abstract in legal, scientific works (journal, mini-thesis, thesis or dissertation).

TABLE 6

OTHER EXAMPLES OF MISTRANSLATION

\begin{tabular}{|c|c|c|}
\hline Bahasa & Mistranslation & English \\
\hline $\begin{array}{l}\text { Memberikan } \\
\text { kredit }\end{array}$ & Giving credit & Give credit \\
\hline $\begin{array}{l}\text { Meminta } \\
\text { jaminan }\end{array}$ & $\begin{array}{l}\text { Guarantee of } \\
\text { return }\end{array}$ & $\begin{array}{l}\text { Ask for a } \\
\text { guarantee }\end{array}$ \\
\hline $\begin{array}{l}\text { Hak } \\
\text { Tanggungan } \\
\text { Permasalahan }\end{array}$ & $\begin{array}{l}\text { The rights of } \\
\text { dependents of the } \\
\text { problem }\end{array}$ & Security Right \\
\hline Pihakkreditur & Creditor party & Creditor \\
\hline $\begin{array}{l}\text { Pengembalian } \\
\text { hutang }\end{array}$ & $\begin{array}{l}\text { The return of the } \\
\text { debt }\end{array}$ & $\begin{array}{l}\text { Repayment of the } \\
\text { debt }\end{array}$ \\
\hline $\begin{array}{l}\text { Eksekusi objek } \\
\text { hak } \\
\text { tanggungan }\end{array}$ & $\begin{array}{l}\text { Execution of the } \\
\text { object of the } \\
\text { mortgage right }\end{array}$ & $\begin{array}{l}\text { Execution of } \\
\text { security right }\end{array}$ \\
\hline $\begin{array}{l}\text { Undang- } \\
\text { undang no. } 4 \\
\text { tahun } 1996\end{array}$ & $\begin{array}{l}\text { Law number } 4 \text { of } \\
1996\end{array}$ & Act No. 4 of 1996 \\
\hline Kredit macet & Stuck credit & Bad credit \\
\hline $\begin{array}{l}\text { Melunasi } \\
\text { hutang debitur } \\
\text { kepada } \\
\text { kreditur }\end{array}$ & $\begin{array}{l}\text { Pay off the debt to } \\
\text { the creditor }\end{array}$ & $\begin{array}{l}\text { Pay off the } \\
\text { debtor's debt to } \\
\text { the creditor }\end{array}$ \\
\hline $\begin{array}{l}\text { Pelelangan } \\
\text { umum }\end{array}$ & General auction & Public auction \\
\hline $\begin{array}{l}\text { Ketua } \\
\text { pengadilan }\end{array}$ & $\begin{array}{l}\text { The chairman of } \\
\text { district court }\end{array}$ & $\begin{array}{l}\text { The head of } \\
\text { district court }\end{array}$ \\
\hline
\end{tabular}

negeri

Objek jaminan Object of as a

yang sulit

dijual

Debitur

mengajukan

perlawanan

Struktur

permodalan

koperasi

Pemupukan

modal

Salah satunya

dalam bentuk

modal

pernyataan

Rapat anggota

Kitab

Undang

Undang

Hukum

Pidana

Pemalsuan

terhadap surat

Memiliki sifat

membahayaka

$n$ umum

Menafsir

pasal 78

Mengajukan

tunutan

dengan

membuat

laporan

Putusan

pengadilan

Kejaksaan

Kebutuhan

akan

perumahan

Menawarkan

perumahan

Membatalkan

perjanjian jual

beli

perumahan

Hukum

pembatalan

secara sepihak

Syarat sah

Klausula

perjanjian

perikata jual

beli rumah

Perlindungan

konsumen guarantee could

be hard to sell

The debtor filed a

fight

Union Capital

structure

Beating capital

One of which is in the form of capital statement

Meeting by the members

Indonesian

Criminal Code

Falsification of

letter

Considered the

nature of the

general harm

Interpreting

article 78

Filed a lawsuit to

make report

Court ruling

Attorney

By the increasing

of a housing

Offering housing

Nullification of the buy and sell agreement

Nullification of the agreement by the customer

The valid requirement

The regulate of the buy and sell agreement of the house

Protection customer laws
Hard-to-sell

object guarantee

The debtor filed a resistance

cooperative Capital structure

Capital accumulation

One of which is in the form of capital investments

Member Meeting

Criminal Code

Falsification of a document Considered a legal harmful nature Interpret the article 78

Field a lawsuit by making report

Pre-trial ruling

Prosecutor

The needs of housing

Offering house

Nullification of the purchase agreement

Unilaterally Nullification Law

Validity of contract The regulate through nullification and force majeure provision Customer protection 


\begin{tabular}{|c|c|c|}
\hline Sepihak & One party & Unilaterally \\
\hline $\begin{array}{l}\text { Peraturan } \\
\text { presiden no. } \\
51 \text { tahun } 2014 \\
\text { Rencana tata }\end{array}$ & $\begin{array}{l}\text { Presidential } \\
\text { regulation no. } 51 \\
\text { year } 2014\end{array}$ & $\begin{array}{l}\text { Presidential } \\
\text { Decree No. } 51 \text { of } \\
2014\end{array}$ \\
\hline $\begin{array}{l}\text { ruang } \\
\text { kawasan } \\
\text { perkotaan }\end{array}$ & $\begin{array}{l}\text { Spatial planning } \\
\text { of urban area }\end{array}$ & Urban spatial plan \\
\hline $\begin{array}{l}\text { Tidak ada } \\
\text { kemanfaatan } \\
\text { hukum di } \\
\text { dalam } \\
\text { peraturan } \\
\text { tersebut }\end{array}$ & $\begin{array}{l}\text { There is no law } \\
\text { benefit in the } \\
\text { regulation }\end{array}$ & $\begin{array}{l}\text { No legal } \\
\text { expediency in } \\
\text { achieving the } \\
\text { regulation }\end{array}$ \\
\hline $\begin{array}{l}\text { Kedaulatan } \\
\text { bangsa }\end{array}$ & $\begin{array}{l}\text { The unity and } \\
\text { sovereignty of the } \\
\text { nation }\end{array}$ & $\begin{array}{l}\text { The sovereignty } \\
\text { of the nation }\end{array}$ \\
\hline $\begin{array}{l}\text { Mengatur } \\
\text { penataan } \\
\text { dalam Teluk } \\
\text { Benoa }\end{array}$ & $\begin{array}{l}\text { Arranging the } \\
\text { arrangement } \\
\text { within Benoa Bay }\end{array}$ & $\begin{array}{l}\text { Adjust the setting } \\
\text { in Benoa Bay }\end{array}$ \\
\hline $\begin{array}{l}\text { Akibat hokum } \\
\text { dari } \\
\text { Peraturan } \\
\text { Daerah } \\
\text { Provinsi Bali } \\
\text { Nomor } 16 \\
\text { Tahun } 2009 \\
\text { Rencana tata }\end{array}$ & $\begin{array}{l}\text { Legal } \\
\text { consequences of } \\
\text { Benoa Bali } \\
\text { Provincial } \\
\text { Regulation no. } 16 \\
\text { year } 2009\end{array}$ & $\begin{array}{l}\text { Legal } \\
\text { consequences of } \\
\text { Local Regulation } \\
\text { in Bali Province } \\
\text { no. } 16 \text { of } 2009\end{array}$ \\
\hline $\begin{array}{l}\text { ruang } \\
\text { kawasan } \\
\text { perkotaan } \\
\text { Sarbagita }\end{array}$ & $\begin{array}{l}\text { Urban Area Plan } \\
\text { Sarbagita }\end{array}$ & $\begin{array}{l}\text { Urban Area Plan } \\
\text { for Sarbagita }\end{array}$ \\
\hline $\begin{array}{l}\text { Peraturan } \\
\text { daerah }\end{array}$ & Local law & Local regulation \\
\hline $\begin{array}{l}\text { Transaksi } \\
\text { pergadangan } \\
\text { luar } \\
\text { Penetapan }\end{array}$ & $\begin{array}{l}\text { Outside trading } \\
\text { transaction }\end{array}$ & $\begin{array}{l}\text { Foreign trading } \\
\text { transaction }\end{array}$ \\
\hline $\begin{array}{l}\text { rupiah } \\
\text { sebagai alat } \\
\text { pembayaran }\end{array}$ & $\begin{array}{l}\text { Set rupiah as a } \\
\text { means of payment }\end{array}$ & $\begin{array}{l}\text { Set rupiah as legal } \\
\text { tender }\end{array}$ \\
\hline $\begin{array}{l}\text { Pelaku usaha } \\
\text { perdagangan } \\
\text { internasional }\end{array}$ & $\begin{array}{l}\text { International trade } \\
\text { business } \\
\text { perpetrators }\end{array}$ & $\begin{array}{l}\text { International trade } \\
\text { business actor }\end{array}$ \\
\hline $\begin{array}{l}\text { Akta } \\
\text { pemberian hak } \\
\text { tanggungan } \\
\text { Pemberi hak }\end{array}$ & $\begin{array}{l}\text { Deed of granting } \\
\text { rights of } \\
\text { dependents }\end{array}$ & $\begin{array}{l}\text { Security right } \\
\text { deed }\end{array}$ \\
\hline $\begin{array}{l}\text { tanggungan } \\
\text { akan } \\
\text { mengosongkan } \\
\text { objek hak } \\
\text { tanggungan } \\
\text { pada waktu } \\
\text { eksekusi hak }\end{array}$ & $\begin{array}{l}\text { The giver of } \\
\text { security will } \\
\text { emptying the } \\
\text { Security Right } \\
\text { objects at the } \\
\text { execution time }\end{array}$ & $\begin{array}{l}\text { The grantor of } \\
\text { security will } \\
\text { vacate the } \\
\text { Security Right } \\
\text { objects at the } \\
\text { execution time }\end{array}$ \\
\hline $\begin{array}{l}\text { tanggungan } \\
\text { Jaminan hak } \\
\text { tanggungan }\end{array}$ & $\begin{array}{l}\text { Guarantee } \\
\text { security right }\end{array}$ & $\begin{array}{l}\text { Mortgage } \\
\text { guarantee }\end{array}$ \\
\hline
\end{tabular}

\begin{tabular}{|c|c|c|}
\hline $\begin{array}{l}\text { Perjanjian } \\
\text { pokok }\end{array}$ & $\begin{array}{l}\text { Principal } \\
\text { agreement }\end{array}$ & Basic agreement \\
\hline $\begin{array}{l}\text { Perjanjian } \\
\text { utang piutang }\end{array}$ & Agreement debs & $\begin{array}{l}\text { Debs agreement } \\
\text { receivable }\end{array}$ \\
\hline $\begin{array}{l}\text { Mengajukan } \\
\text { lelang kepada } \\
\text { BLBI }\end{array}$ & $\begin{array}{l}\text { Submit to the } \\
\text { BLBI auction }\end{array}$ & $\begin{array}{l}\text { Filed auction to } \\
\text { BLBI }\end{array}$ \\
\hline $\begin{array}{l}\text { Pengosongan } \\
\text { objek }\end{array}$ & Cleaning object & $\begin{array}{l}\text { Emptying of } \\
\text { object }\end{array}$ \\
\hline $\begin{array}{l}\text { Badan hukum } \\
\text { public atau } \\
\text { privat }\end{array}$ & $\begin{array}{l}\text { Legal institution } \\
\text { of public or } \\
\text { private }\end{array}$ & $\begin{array}{l}\text { Legal entity of } \\
\text { public or private }\end{array}$ \\
\hline $\begin{array}{l}\text { Perseroan } \\
\text { terbatas }\end{array}$ & Limited company & $\begin{array}{l}\text { Limited liability } \\
\text { company }\end{array}$ \\
\hline Badan hukum & Law body & Legal entity \\
\hline Subjek hukum & $\begin{array}{l}\text { Legal subject of } \\
\text { law }\end{array}$ & Legal subject \\
\hline $\begin{array}{l}\text { Kekurangan } \\
\text { modal }\end{array}$ & Increase capital & Lack of modal \\
\hline $\begin{array}{l}\text { Pengaturan } \\
\text { rekapitalisasi }\end{array}$ & $\begin{array}{l}\text { Recapitalization } \\
\text { setting }\end{array}$ & $\begin{array}{l}\text { The } \\
\text { recapitalization of } \\
\text { arrangement }\end{array}$ \\
\hline Sistem voting & Vote system & Voting system \\
\hline $\begin{array}{l}\text { Undang- } \\
\text { undang no. } 40 \\
\text { tahun } 2007\end{array}$ & $\begin{array}{l}\text { Law no } 40 \text { year } \\
2007\end{array}$ & $\begin{array}{l}\text { Act No. } 40 \text { of } \\
2007\end{array}$ \\
\hline $\begin{array}{l}\text { Saham } \\
\text { mayoritas }\end{array}$ & Majority share & $\begin{array}{l}\text { Majority } \\
\text { shareholders }\end{array}$ \\
\hline $\begin{array}{l}\text { Sengketa } \\
\text { pajak }\end{array}$ & $\begin{array}{l}\text { Legal action of } \\
\operatorname{tax}\end{array}$ & Tax disputes \\
\hline $\begin{array}{l}\text { Upaya hukum } \\
\text { keberatan }\end{array}$ & $\begin{array}{l}\text { Legal remedy of } \\
\text { appeal }\end{array}$ & $\begin{array}{l}\text { Remedis } \\
\text { Objection }\end{array}$ \\
\hline $\begin{array}{l}\text { Lembaga } \\
\text { pengadilan } \\
\text { pajak }\end{array}$ & $\begin{array}{l}\text { Tax court } \\
\text { institution }\end{array}$ & Tax court \\
\hline $\begin{array}{l}\text { Aparat } \\
\text { penegak } \\
\text { hukum }\end{array}$ & $\begin{array}{l}\text { The agent of law } \\
\text { enforce }\end{array}$ & $\begin{array}{l}\text { Law enforcement } \\
\text { officers }\end{array}$ \\
\hline $\begin{array}{l}\text { Budaya hukum } \\
\text { dari } \\
\text { masyarakat }\end{array}$ & $\begin{array}{l}\text { Culture Law from } \\
\text { society }\end{array}$ & $\begin{array}{l}\text { Law culture of the } \\
\text { society }\end{array}$ \\
\hline $\begin{array}{l}\text { Direktorat } \\
\text { jenderal pajak } \\
\text { kantor } \\
\text { wilayah Bali }\end{array}$ & $\begin{array}{l}\text { DirectoralJendral } \\
\text { Tax on Bali }\end{array}$ & $\begin{array}{l}\text { Directorate } \\
\text { Gendral of } \\
\text { Taxitaion in Bali }\end{array}$ \\
\hline Wajib pajak & Required Tax & Taxpayer \\
\hline $\begin{array}{l}\text { Upaya Hukum } \\
\text { Keberatan }\end{array}$ & Legal Objection & $\begin{array}{l}\text { Remedies } \\
\text { Objection }\end{array}$ \\
\hline Efektivitas & Effectiveness & Legal \\
\hline Hukum & Legal & Effectiveness \\
\hline
\end{tabular}

Relevant to the above analysis, the result of empirical research also indicates that as many as $40 \%$ of respondents, who are abstract authors of scientific works in the field of law, translate abstract from Bahasa into English by using online translation engine; as much as $40 \%$ using the services of colleagues who mostly have lack legal background and knowledge; and as much as $20 \%$ translate the abstract itself. As mentioned previously, the 
mistranslations in legal abstract from Bahasa into English, generally occur due to the use of online translation engine by abstract authors without them (the authors) paying attention to the structure of standard academic writing (S-P$\mathrm{O})$ in the source language or ask for help colleagues who mostly have lack of legal backgrounds and knowledge. In more detail, such result of empirical research is shown in diagram 2 below:

DIAGRAM 2

AUTHOR'S EXPERIENCE IN TRANSLATING ABSTRACT IN LAW FIELD FROM BAHASA INTO ENGLISH

\section{Author's Experience in Translating Abstract in Law Field from Bahasa...}

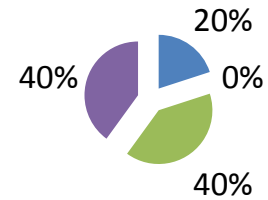

I translate it my self

The diagram processed from the result of empirical research towards respondents who are abstract authors of journal / mini-thesis / thesis/dissertation in the field of law.

\section{CONCLUSION}

The translation process from a source language into the target language without knowing the conceptual meaning will lead to misunderstanding. The misuse of legal English terminology may occur due to the word for word translation, free translation and literal translation.In line with that, based on empirical research, such misuse occurred due to the use of online translation engine which mostly caused by the ignorance of abstract's authors on the structure of standard academic writing (S-P-O) in the source language and asking help from colleagues who mostly do not have legal background and has minimum knowledge of legal English terminology. Thus, in translating legal abstract of scientific works, it is very important for the authors to avoid the methods of word for word, free and literal translations without paying attention to the conceptual meaning of the terms, phrases or sentences both in source and target languages.

\section{ACKNOWLEDGMENT}

Authors would like to say thank you very much to Faculty of Law Udayana University and
LembagaPenelitiandanPengabdianMasyarakat of Udayana Universityfor all the supports.

\section{REFERENCES}

[1] Catford, J.C."A Linguistic Theory of Translation". London: Oxford University Press. 1965

[2] Mildred L Larson. "Meaning-Based Translation: A Guide To CrossLanguage Equivalence". USA: University Press of Amerika. 1986

[3] E.A Nida and Charles R. Taber. "The Theory and Practice of Translation.” Leiden: E.J. Brills. 1974. 